\title{
Bioreactor and Bioprocess Design Issues in Enzymatic Hydrolysis of Lignocellulosic Biomass
}

\author{
Giuseppe Olivieri $^{1, *}$, René H. Wijffels ${ }^{1,2}$, Antonio Marzocchella ${ }^{3}$ and Maria Elena Russo ${ }^{4, *(D)}$ \\ 1 Bioprocess Engineering Group, Department of Agrotechnology and Food Sciences, Wageningen University \\ and Research, P.O. Box 16, 6700 AA Wageningen, The Netherlands; rene.wijffels@wur.nl \\ 2 Faculty of Biosciences and Aquaculture, Nord University, N-8049 Bodø, Norway \\ 3 Dipartimento di Ingegneria Chimica dei Materiali e della Produzione Industriale, Università degli Studi di \\ Napoli Federico II, P.le V. Tecchio 80, 80125 Napoli, Italy; antonio.marzocchella@unina.it \\ 4 Istituto di Scienze e Tecnologie per l'Energia e la Mobilità Sostenibili, Consiglio Nazionale delle Ricerche, \\ P.le V. Tecchio 80, 80125 Napoli, Italy \\ * Correspondence: giuseppe.olivieri@wur.nl (G.O.); mariaelena.russo@stems.cnr.it (M.E.R.)
}

Citation: Olivieri, G.; Wijffels, R.H.; Marzocchella, A.; Russo, M.E. Bioreactor and Bioprocess Design Issues in Enzymatic Hydrolysis of Lignocellulosic Biomass. Catalysts 2021, 11, 680. https://doi.org/ $10.3390 /$ catal11060680

Academic Editor: Felix Garcia-Ochoa

Received: 12 May 2021

Accepted: 24 May 2021

Published: 27 May 2021

Publisher's Note: MDPI stays neutral with regard to jurisdictional claims in published maps and institutional affiliations.

Copyright: (c) 2021 by the authors. Licensee MDPI, Basel, Switzerland. This article is an open access article distributed under the terms and conditions of the Creative Commons Attribution (CC BY) license (https:/ / creativecommons.org/licenses/by/ $4.0 /)$.

\begin{abstract}
Saccharification of lignocellulosic biomass is a fundamental step in the biorefinery of second generation feedstock. The physicochemical and enzymatic processes for the depolymerization of biomass into simple sugars has been achieved through numerous studies in several disciplines. The present review discusses the development of technologies for enzymatic saccharification in industrial processes. The kinetics of cellulolytic enzymes involved in polysaccharide hydrolysis has been discussed as the starting point for the design of the most promising bioreactor configurations. The main process configurations-proposed so far-for biomass saccharification have been analyzed. Attention was paid to bioreactor configurations, operating modes and possible integrations of this operation within the biorefinery. The focus is on minimizing the effects of product inhibition on enzymes, maximizing yields and concentration of sugars in the hydrolysate, and reducing the impact of enzyme cost on the whole process. The last part of the review is focused on an emerging process based on the catalytic action of laccase applied to lignin depolymerization as an alternative to the consolidated physicochemical pretreatments. The laccases-based oxidative process has been discussed in terms of characteristics that can affect the development of a bioreactor unit where laccases or a laccase-mediator system can be used for biomass delignification.
\end{abstract}

Keywords: saccharification; cellulase; laccase; kinetics; reactor design

\section{Introduction}

Lignocellulosic biomass is currently the main exploited feedstock in several value chains of the bio-based economy. Lignocellulose is a complex vegetable matrix consisting of different macromolecules: cellulose, hemicellulose and lignin. The recovery of monomeric sugars and their fermentation represents the central core of most of the biorefineries based on lignocellulosic feedstock. Indeed, many commercial bio-based products are produced by fermentation of these monomers: alcohols (ethanol, butanol, 1,4-butanediol and 1,3-propanendiol), carboxylic acids (acetic acid, lactic acid and itaconic acid), and esters (ethylacetate). Several others are in a late development stage and are close to market maturity, such as succinic acid, adipic acid, xylitol and polyhydroxyalkanoate. The hydrolysis of cellulose and hemicellulose can be effectively achieved via a chemical route performed at high temperature $\left(>200{ }^{\circ} \mathrm{C}\right)$ and pressure $(>20$ bars $)$ and under strong acidic conditions $(\mathrm{pH}<2)$. However, several by-products can be formed under such severe conditions; their presence in the hydrolysate is strongly undesired because they inhibit the subsequent fermentation process. For these reasons, the enzymatic hydrolysis of cellulose and hemicellulose by cellulolytic enzymes has been developed up to the industrial scale and is currently the benchmark technique, in sugar-based biorefinery, to 
perform a selective hydrolysis of the glucosidic bonds and minimize the formation of by-products [1-3] (Figure 1). Access of cellulolytic enzymes to polysaccharides is hindered by the lignin fraction of the biomass. Lignin is an amorphous heteropolymer made of several crosslinked aromatic monomers, all derived from phenylpropane, among which the most abundant are paracoumaryl alcohol, coniferyl alcohol and sinapyl alcohol. The lignin matrix very often entangles the structure of the cellulose and hemicellulose polymer in the vegetable biomass, conferring the rigidity to the structure. However, it strongly limits the accessibility of the cellulose and hemicellulose by the cellulolytic enzymes into lignocellulose biomass. Therefore, a pretreatment step of partial hydrolysis of lignin is required to disentangle it from the saccharides fraction of lignocellulose [4,5].

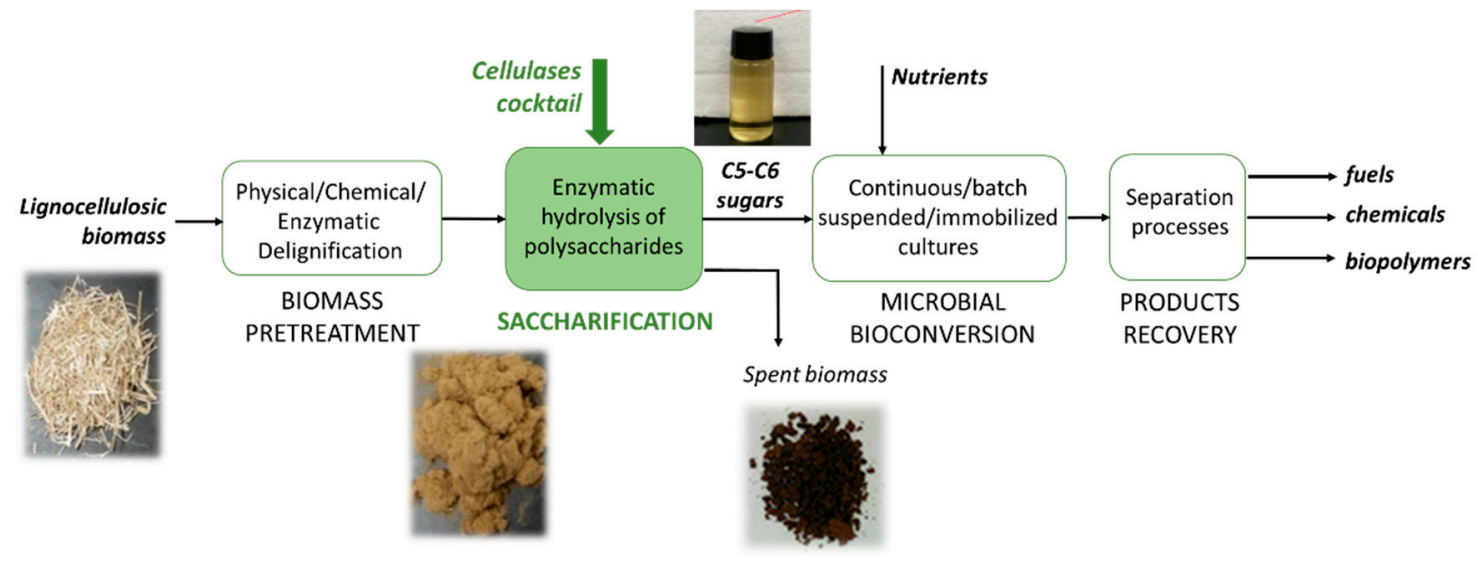

Figure 1. Block diagram of a sugar-based biorefinery.

Multiple pretreatment steps are available, which are based on combined mechanical, physical and chemical processes designed to enhance the efficiency of the subsequent enzymatic hydrolysis of cellulose and hemicellulose. This desired result should be associated with a threshold delignification value, but such a standardization is hard to obtain due to large variability of biomass composition (lignin content ranges between 15 and $30 \%$ wt for softwood, hardwood and straw stalks biomass [6]) and due to the principles of each pretreatment process (see comprehensive review by Sheng et al. [7]). Conventional pretreatments (steam-explosion, acid and alkaline hot treatments in aqueous solvents) allow the removal of lignin (disruption or chemical decomposition) from the solid substrate. In these cases, the harsher the conditions of such unspecified processes, the larger the extent of the hydrolysis of polysaccharides (especially hemicellulose). The enzymatic hydrolysis of cellulose and hemicellulose in plants occurs in nature by the action of ligninolytic microorganisms such as fungi. In particular, white-rot and brown-rot fungi are also able to oxidize lignin by means of laccases and lignin peroxidases in order to gain accessibility to the cellulose $[8,9]$. Among the novel pretreatments currently studied, the laccase catalysed oxidation of lignin is the only enzymatic process. It is discussed in Section 3 as a potential route towards a fully enzymatic saccharification process that may be achieved using both laccases and cellulases, avoiding the use of other organic solvents or chemical pretreatments.

The enzymatic hydrolysis of cellulose and hemicellulose involves a particular class of enzymes: non-complexed and complexed cellulases. The biochemistry of cellulases have been extensively studied in the last 20 years in view of the industrial application of the biorefinery of lignocellulose. The conventional operation at an industrial scale makes use of mixtures of cellulases. The mixtures include exoglucanases and endoglucanases that catalyse the hydrolysis of cellulose and produce oligosaccharides such as cellobiose. High concentrations of $\beta$-glucosidases are supplemented to the mixture to catalyse the hydrolysis of cellobiose into glucose as the only final product of the whole process. After the pretreatment, the delignified biomass appears as a dispersed phase of expanded soft 
granules characterized by irregular geometric features (wide particle size distribution, broad porosity and irregular shape). Consequently, the industrial saccharification operation occurs through heterogeneous liquid-solid reactions catalysed by: the substrates that are the solid granules of delignified biomass, the products in the liquid phase that are the sugar monomers produced by the hydrolysis, and the enzymes that are the soluble biocatalysts also dissolved into the liquid phase. The reaction can occur if the cellulase adsorbs and binds on the reaction sites of hydrolysis over the biomass surface. The main steps of the enzymatic hydrolysis mechanisms are detailed in Section 2, together with some relevant approaches to model kinetics for bioreactor design purposes. When a hydrolysis step is performed, the enzyme moves along the cellulose chain, performing the hydrolysis of $\beta$-glucosidic bonds. Some studies pointed out that the enzyme does not really desorb from one reacted site and adsorb on the next one in space, but it better moves from one reaction site to another, still keeping its adsorbed state $[8,10]$. Thus, the limited accessibility of the biomass by the enzyme represents the main kinetic bottleneck of the operation. The limitation can be due by both the mass transfer of the enzyme in the porous structure and the adsorption on the reaction site of the biomass.

Bioreactors performing the enzymatic hydrolysis require a certain level of agitation to promote the mass transfer and mixing of the phases. The time scale of the operation is quite long (more than $48 \mathrm{~h}$ ) and can be shortened by increasing the enzyme loading of the reactor. However, as the enzyme is one of the most costly items, this would obviously affect the economy of the operation [11]. Currently, cellulase cost ranges between 3 and 300 Euro $/ \mathrm{kg}$. For example, in the case of ethanol production from lignocellulose biomass, this counts for 0.05-1 Euro/ $\mathrm{kg}$ of the total production cost [11]. Thus, the operation asks for a careful design of the bioreactor and an efficient use of enzymes as biocatalysts $[8,12]$. The main open issues revealed by the current state of the art are: (i) the balance between high sugar yield (favored at diluted biomass working conditions-about $5 \% \mathrm{wt}$ ) and high sugar concentrations in the liquid hydrolysate (favored in bioreactors working at high solid loading $>15 \% \mathrm{wt}$ ); (ii) the variability of biomass composition, typically affecting second generation biorefinery, based on the valorization of lignocellulosic wastes that avoids a comprehensive assessment of heterogeneous hydrolysis kinetics; and (iii) the continuous use of the enzymes and difficult recycling hindered by the nature of the process involving the adsorption of the biocatalyst on the solid substrate.

This review addresses fundamental aspects and possible strategies that play a role at different scales in solving the above-mentioned crucial issues. The attention goes from the microscale (kinetics) to the macroscale (bioreactor and process integration) through the following sections, including literature analysis and discussion: (1) the kinetics of heterogeneous hydrolysis of lignocellulosic biomass catalysed by cellulases and modelling approaches as a basis for process and bioreactor design; (2) the principles of process design for saccharification and fermentation processes to maximize sugar and final product yields; (3) bioreactor design strategies to accomplish batch and continuous enzymatic hydrolysis of lignocellulosic biomasses; (4) the enzymatic depolymerisation of lignin catalysed by laccases as a potential process that may enable a fully enzymatic saccharification of biomasses.

\section{Kinetic Models of Enzymatic Cellulose Hydrolysis}

Cellulose is a crystalline homopolymer made of glucose monomers. Hemicellulose represents a variety of partial crystalline heteropolymers: xylan, glucuronoxylan, arabinoxylan, glucomannan, and xyloglucan. Differently from cellulose, sugar monomers in hemicellulose include not only glucose but also other C6 (mainly mannose, galactose and rhamnose) and C5 monosaccharides (xylose and arabinose). When the $\beta$-glucosidic bonds among the monomers of both cellulose and hemicellulose are hydrolysed, the lignocellulose biomass converted is a mixture of fermentable sugars. This process can occur when a substrate deriving from a real lignocelullosic biomass is placed into contact with a mixture of cellulases and hemicellulases. 
Kinetic models of enzymatic reactions are used in the rational design of bioreactors according to the typical approach of chemical reactor engineering. In the case of enzymatic hydrolysis of cellulose applied to the saccharification of lignocellulosic biomasses, the use of kinetic models in bioreactor design is not a trivial issue. This is due to the heterogeneous nature of the process and the variability of the biomass feedstock (as in a second generation biorefinery), so this topic has been often addressed using simplified approaches that are far from the deep knowledge of cellulase mechanism reported in some of the literature. The current state of the art has been reported by Jeoh et al. [13] in a recent review paper. They surveyed the most detailed mechanistic models of cellulose hydrolysis catalyzed by cellulases. The main steps of the general mechanism are reported in Figure 2 and include: (i) enzyme transport from the liquid bulk to the surface of biomass granules by convective and diffusive mechanisms; (ii) enzyme adsorption on the biomass surface (throughout the complex structure of polysaccharides and lignin); (iii) complexation of the polysaccharide chain (substrate) and the active site of the enzyme molecule; (iv) hydrolysis of polysaccharides by the adsorbed enzymes, reaction, and release of products; (v) product transport to the liquid bulk; (vi) homogeneous hydrolysis of soluble oligomers (e.g., cellobiose) in the liquid phase catalysed by $\beta$-glucosidase; and (vii) enzyme desorption from the biomass surface.

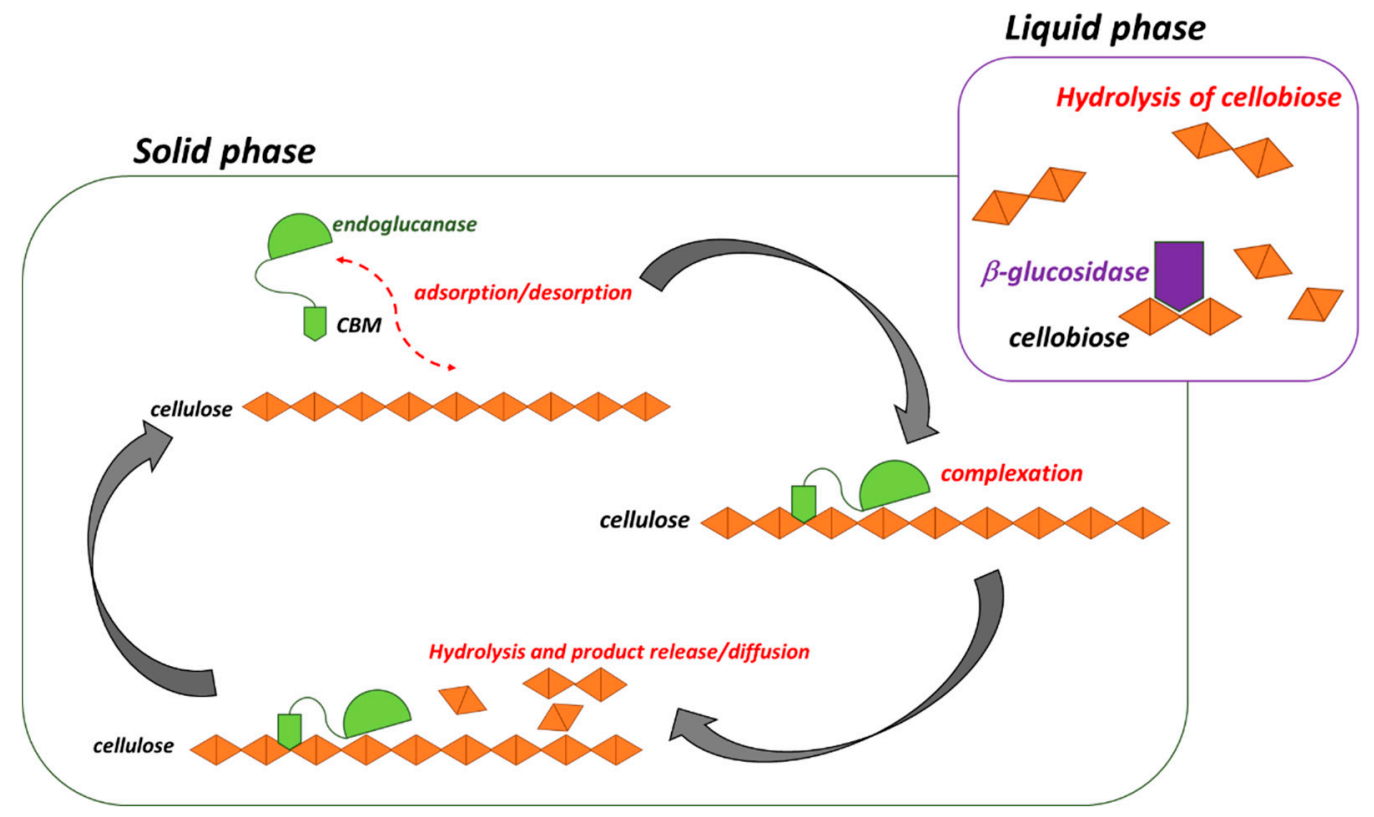

Figure 2. Illustration of the main steps of the cyclic mechanism of interaction between the hydrolytic enzyme molecule and cellulose chain [13]. CBM-Cellulose Binding Module.

The rate limiting step is the complexation or decomplexation between the enzyme (endoglucanase or exoglucanase) and the cellulose chain. Kinetic parameters assessed for this step range between $10^{-4}$ and $5 \times 10^{-3} \mathrm{~s}^{-1}$. These values are almost one half of the kinetic parameters assessed for enzyme adsorption and almost three orders of magnitude lower than glycosidic bond hydrolysis parameters $\left(1-7 \mathrm{~s}^{-1}\right)$. Most of the models assessing the initial rate were fitted against data from hydrolysis tests carried out using microcrystalline cellulose (MCC) as a substrate. This method provided deep insight into the enzyme mechanisms, but hinders the validation of the kinetic models against the hydrolysis of cellulose as a component of a real biomass feedstock. Jeoh et al. [13] showed how even detailed mechanistic models cannot be used for design purposes because of the large variability of the biomass structures. As a matter of fact, most of the models assessed through "initial rate" tests using MCC as substrate fail in predicting the long term conversion of real biomass samples. 
This evidence has supported the development of approaches different from mechanistic models to the aim of reactor design for lignocellulosic biomass hydrolysis. Bansal et al. [10] reviewed different types of models including empirical models that, even if limited to a specific lignocellulosic substrate, provide effective mathematical tools to predict performances of batch or continuous reactors. Other attempts to adjust the long-term prevision of sugar production dynamics and yields included the use of product inhibition [14,15] and biomass recalcitrance [16] as additional terms of the kinetic model. In addition, diffusion limited models, such as Chrastil's model [17] (see equation in Table 1), can be safely applied if the limit conversion (maximum sugar concentration) is provided by bench scale tests $[18,19]$. This type of model is aimed at describing the effect of substrate structure on the rate of glucose production, so, in addition to the kinetic parameter $k$, the $n$ parameter describes the effect of soluble species diffusion into the porous structure of the biomass $(n \rightarrow 1$ negligible diffusion limitation, $0<n<1$ diffusion limited regime).

Sousa et al. [20] made another attempt, through a survey of the literature, to give guidelines on the selection of kinetic models of enzymatic hydrolysis of cellulose whenever they are applied to bioreactor design. They stated that it is not safe to extend the predictions of models retrieved from experimental assessments of a certain biomass to a different one. This comment suggests the application of an ad-hoc characterization of kinetics for each potential biomass feedstock, whose composition variability depends not only on the biomass origin but also on the delignification pretreatment. This approach seems time consuming but its impact and efficacy can be improved if a common approach would be applied in the assessment of hydrolysis kinetic against real delignified biomass feedstock. As an example, the selection of proper mixing conditions is hardly considered among the operational parameters that influence the validity of bench-scale hydrolysis tests, and Gan et al. [21] observed how most of the studies ignore the effects of external mass transfer on the overall sugar production rate. Pratto et al. [18] and Procentese et al. [19] proved that the mixing rate should be selected first since the initial glucose production rate (over $60 \mathrm{~min}$ ) is highly affected by the mixing speed. They assessed the threshold value of mixing speed, above which a constant glucose production rate was observed. Then, the effect of substrate and enzyme concentrations on the initial rate and long term dynamics was characterized at a fixed mixing speed that was slightly larger than the threshold value. These values were about $200 \mathrm{rpm}$ for hydrothermally pretreated sugarcane straw [18] in mixed Erlenmeyer flasks, and varied between 180 and $300 \mathrm{rpm}$ for apple residues [19] processed in a stirred bench scale glass vessel $(250 \mathrm{~mL})$, depending on the delignification pretreatment applied. 
Table 1. Glucose production rate values described by semi-mechanistic models.

\begin{tabular}{|c|c|c|c|c|c|c|}
\hline Ref. & $\begin{array}{l}\text { Rate of Glucose } \\
\text { Production, } \\
\text { g/L min }\end{array}$ & Type of Tests & Type of Model and Equations & Reactor/Volume & Biomass/Substrate & Enzymes \\
\hline [18] & $0.055-0.3$ & \multirow[t]{2}{*}{$\begin{array}{c}\text { Initial rate }(60 \mathrm{~min}) \text { and } \\
\text { long term }(48 \mathrm{~h}) \\
\text { tests for kinetic } \\
\text { model assessment }\end{array}$} & $\begin{array}{c}\text { Semi-mechanistic } \\
\text { (M\&M product inhibition: } \\
V_{\max } 0.057-0.114 \mathrm{~g} /(\mathrm{L} \text { min }), \\
K_{m} 9.6-13.1 \mathrm{~g} / \mathrm{L} \\
K_{i} 0.58-0.84 \mathrm{~g} / \mathrm{L} . \\
V=\frac{V_{\max } S}{K_{m}\left(1+P / K_{i}\right) S} \\
\text { Modified } M \& M \text { product inhibition : } \\
k 5-610^{-3} \min ^{-1}, K_{e} 7.9-12.5 \mathrm{~g} / \mathrm{L}, \\
K_{i} 3.9-9.4 \mathrm{~g} / \mathrm{L} . \\
V=\frac{V_{\max } E_{0}}{K_{m}\left(1+P / K_{i}\right) E_{0}} \\
\text { Chrastil's: } k 2.9-7.410^{-5} \mathrm{~L} /(\mathrm{g} \min ) \\
n 0.41-0.63) . \\
P=P_{\max }\left(1-\exp \left(-k E_{0} t\right)\right)^{n}\end{array}$ & $\begin{array}{l}\text { Stirred Erlenmeyer } \\
\text { flasks } / 250 \mathrm{~mL}\end{array}$ & $\begin{array}{l}\text { Sugarcane straw } \\
\text { (SCS)/raw and } \\
\text { hydrothermally } \\
\text { pretreated SCS }\end{array}$ & \multirow[t]{2}{*}{ Cellic ${ }^{\circledR}$ CTec2 } \\
\hline [19] & $0.04-0.09$ & & $\begin{array}{c}\text { Semi-mechanistic (M\&M product } \\
\text { inhibition: } V_{\max } 0.067-0.3 \mathrm{~g} \mathrm{~L}^{-1} \mathrm{~min}^{-1} \\
K_{m} 5.5-9 \mathrm{~g} \mathrm{~L}-1, K_{i} 0.16-0.31 \mathrm{~g} / \mathrm{L} \\
\text { Chrastil's: } k \text { } 2-1.110^{-3} \mathrm{Lg}^{-1} \mathrm{~min}^{-1} \\
n 0.38-0.46)\end{array}$ & $\begin{array}{l}\text { Stirred cell reactor } \\
\text { (Applikon minibio)/ } \\
250 \mathrm{~mL}\end{array}$ & Apple pomace & \\
\hline [15] & $\begin{array}{c}0.017-0.083 \\
\text { (Productivity) }\end{array}$ & $\begin{array}{l}\text { Enzyme } \\
\text { adsorption/Continuous } \\
\text { hydrolysis tests } \\
\text { compared with } \\
\text { predictive model results }\end{array}$ & $\begin{array}{l}\text { Adsorption/desorption of cellulases } \\
\text { kinetics/hydrolysis is a network of four } \\
\text { parallel reactions: two substrates } \\
\text { (crystalline and amorphous cellulose) } \\
\text { and two products (cellobiose and } \\
\text { glucose). M\&M product inhibition + } \\
\text { enzyme inactivation + enzyme } \\
\text { desorption (see original paper). }\end{array}$ & Glass columns $/ 4-80 \mathrm{~mL}$ & $\begin{array}{c}\text { Cellulose } \\
\text { (from cotton stalks) }\end{array}$ & $\begin{array}{l}\text { Cellulase from } \\
\text { Trichoderma } \\
\text { longibrachiatum }\end{array}$ \\
\hline
\end{tabular}


Table 1. Cont.

\begin{tabular}{|c|c|c|c|c|c|c|}
\hline Ref. & $\begin{array}{l}\text { Rate of Glucose } \\
\text { Production, } \\
\text { g/L min }\end{array}$ & Type of Tests & Type of Model and Equations & Reactor/Volume & Biomass/Substrate & Enzymes \\
\hline$[21,22]$ & Not reported & $\begin{array}{l}\text { Batch/fed- } \\
\text { batch/continuous tests } \\
\text { compared with } \\
\text { predictive model results }\end{array}$ & $\begin{array}{c}\text { Mechanistic model: Two substrates } \\
\text { (hydrolysable cellulose, inert cellulose), } \\
\text { enzyme loss through inert binding, } \\
\text { shear enzyme deactivation, competitive } \\
\text { product inhibition. Primary rate } \\
\text { constant of enzyme hydrolyzable } \\
\text { cellulose complex } \\
\text { formation } / \text { consumption: } \\
0.2 \mathrm{~s}^{-1} / 0.05 \mathrm{M}^{-1} \mathrm{~s}^{-1} \text {; rate of product } \\
\text { formation: } 9.05 \mathrm{~s}^{-1} \text { (see Gan et al. [21] } \\
\text { for complete description of equations) }\end{array}$ & $\begin{array}{c}\text { Strirred cell }+ \\
\text { ultrafiltration } \\
\text { membrane } / 2.5 \mathrm{~L}\end{array}$ & $\begin{array}{c}\text { Purified and } \\
\text { pulverized cellulose } \\
\left(38-10610^{-6} \mathrm{~m}\right)\end{array}$ & $\begin{array}{l}\text { Cellulase from } \\
\text { Trichoderma reesei } \\
\text { (Sigma C8546) }\end{array}$ \\
\hline [16] & 0.007 & $\begin{array}{l}\text { Initial rate tests } \\
\text { (15-60 min) for kinetic } \\
\text { model assessment }\end{array}$ & $\begin{array}{l}\text { Semi-mechanistic model: linear } \\
\text { dependence on cellulose concentration, } \\
\text { Langmuir type dependence of max rate } \\
\text { of hydrolysis on enzyme concentration, } \\
\text { glucose inhibition, enzyme deactivation } \\
\text { by temperature, substrate recalcitrance } \\
\text { (See Equation 10, 11, and } 12 \text { of the } \\
\text { original reference for rate equations of } \\
\text { conversion of cellulose into cellobiose, } \\
\text { cellobiose into glucose, and cellulose } \\
\text { into glucose, respectively) }\end{array}$ & $\begin{array}{c}\text { Test tube (total working } \\
\text { volume } 6 \mathrm{~mL} \text { ) } \\
\text { on vertical rotator }\end{array}$ & $\begin{array}{l}\text { Cellulose (Avicel } \\
\text { and Whatman, } \\
\text { No. 1,001,090 filter Paper) } \\
\text { and wheat straw }\end{array}$ & $\begin{array}{l}\text { Cellubrix, Celluclast, } \\
\text { Novozymes } 188 \\
\text { (Novozymes Corp., Denmark) }\end{array}$ \\
\hline
\end{tabular}


Some relevant examples of experimental studies including modelling of brief and longterm enzymatic hydrolysis of cellulose from different sources are reported in Table 1. Rate equations for the most common models are reported together with values of parameters in Table 1; more complex models $[15,21,22]$ are described in terms of the main phenomena that are taken into account in model development. In the latter case, the reader should refer to the original articles for complete rate equations. The reported values of kinetic parameters give an idea of the order of magnitude of the main steps of the considered mechanisms, which, in most of the cases, includes the conversion of cellulose into cellobiose and of cellobiose into glucose $[15,16,21,22]$, as well as the direct conversion of cellulose into glucose $[15,16]$. Studies by Gusakov et al. $[14,15]$ and by Gan et al. [21,22] showed how mechanistic models can be developed and applied with predictive purposes to describe the performances of lab scale $\left(4 \times 10^{-3}\right.$ to $\left.2.5 \mathrm{~L}\right)$ batch and continuous reactors (tubular [15] and stirred $[21,22])$. In both cases, the substrate was purified cellulose, and in the study reported by Gan et al. [21,22] it was characterized in terms of micro-particle size distribution. The latter feature was used to develop the model through the concept of surface distribution of the hydrolyzable and inert portions of the substrate particles. This approach successfully allowed the description of the lowering rate of sugar production occurring at increasing degrees of cellulose conversion. Similarly, a successful description of this phenomenon was achieved by Drissen et al. [16] by including a "substrate recalcitrance" term in a semimechanistic model (see Table 1), where the dependence on enzyme concentration was described through a Langmuir-type term. The model parameters were assessed for both Avicel ${ }^{\circledR}$ (as ideal cellulose substrate) and alkaline-pretreated wheat straw.

The reported scenario suggests that the intrinsic variability of reaction rate during the conversion of polysaccharides into soluble sugars asks for characterization of kinetic models whenever a certain type of pretreated biomass is selected as feedstock. To this end, the common use of reliable procedures for the assessment of kinetic models describing the enzymatic hydrolysis against a variety of substrates is highly desirable. Such procedures should be consistent with small-scale tests, should take into account the effect of slurry mixing on the sugar production rate, should allow the characterization of biomass (structure, size and polysaccharides fraction), and should minimize the impact of time spent on the analysis of the hydrolysate composition dynamics. The reported literature (Table 1) shows how the comparison between several models $[18,19]$ and/or the development of models that include a variety of phenomena (e.g., adsorption, substrate reactivity) $[15,16,21]$ are necessary to provide reliable tools to predict hydrolysis performance and enable reactor design. In addition, it would be desirable to extend such approaches to groups of biomass feedstock that are as large as possible in order to further demonstrate their effectiveness.

\section{Process Design}

Enzymatic hydrolysis can be implemented according to a simple scheme with batch conversion units supplemented with the proper amount of the enzymes' cocktail. The complex process of enzymatic hydrolysis occurs at a satisfactory rate of conversion whenever a sample of lignocellulosic biomasses (e.g., agro-food wastes) is mixed at temperatures close to $50{ }^{\circ} \mathrm{C}$ with cellulase and hemicellulase cocktails (most of these are commercially available). The benchmark technology of the process to convert lignocellulosic biomass to added value chemicals assembles the three steps (biomass pretreatment, saccharification and fermentative conversion of hydrolysed sugars) in a short sequence of three unit operations, performed in three different pieces of equipment. Furthermore, this basic scheme often does not include the production of cellulolytic enzymes that are supplied as biocatalysts by a third party. Several bio-ethanol production plants (at Abengoa, DuPont, POET-DSM, Tianguan Biofuel, Ineos, GranBio, and Mossi \& Ghisolfi $[23,24]$ ) are currently running according to this straightforward process scheme. However, the cost of cellulases is one of the main economic bottlenecks for the industrial scale implementation of lignocellulosic biorefinery [25]. Techno-economic analysis of the production cost of cellulase in the literature gives a quite broad range for the unit cost of cellulase: 3-300 Euro/ $\mathrm{kg}[11,12,26-32]$. Many 
of these analyses rely on using glucose as carbon source for the fermentative production of cellulase. Realistic cellulase cost ranges between 3 and 8 Euro/kg [12,29]. Assuming an enzyme loading per unit of cellulose ranging between 10 and $30 \mathrm{mg} / \mathrm{g}$ [9], cellulose contents within the biomass of between 30 and 70\%, and efficiency of hydrolysis ranging between $70 \%$ and $90 \%$, the final impact of the cellulase per sugar produced is $0.09 \pm 0.05 \mathrm{Euro} / \mathrm{kg}$, which results in 0.18 Euro $/ \mathrm{kg}$ of lignocellulose biomass. This figure is slightly lower than the market price of sugar from sugar cane [12,29], which still makes the biorefinery based on lignocellulose competitive with respect to the first generation biorefinery.

Klein-Marcuschamer et al. [29] indicated that the main costs of the production of cellulase are, first, the investment ( $\sim 50 \%$, mainly the fermenter cost), and then the materials $(\sim 30 \%$, mainly the sugar substrate for the fermentation). Several efforts have been made to reduce the biocatalyst cost via metabolic engineering, strain improvement and the use of a recombinant strategy for the producer strains [33,34], and optimization of the production via submerged and solid-state fermentations [34,35]. Enhancement of cellulase expression from 1.2 up to 8.5 times with respect to the wild strain has been reported [34,35]. This would potentially lead to a realistic decrease in enzyme cost of as much as two times, if not more. However, none of these studies have been validated at scales that are relevant for a reliable techno-economic analysis.

The production of cellulase embedded in the same biorefinery plant but in a separate operation has been pursued, especially when the scale economy allows advantages. The economic advantage of implementing this process strategy in the case of an ethanol plants has been demonstrated and it allowed a decrease of at least $10 \%$ of the production cost $[23,28,31,36]$. However, with the investment being the most significant cost in enzyme production, several process integration approaches have been proposed, as described by the schemes reported in Figure 3. The logical route pointed out by many attempts in the literature is to integrate enzyme production and polysaccharides hydrolysis in a single step to save both equipment and material costs [37]. Indeed, the same bioreactor could be adopted for the production of cellulase and the hydrolysis of the cellulose. Furthermore, part of the produced glucose would be used as substrate for the production of cellulase.
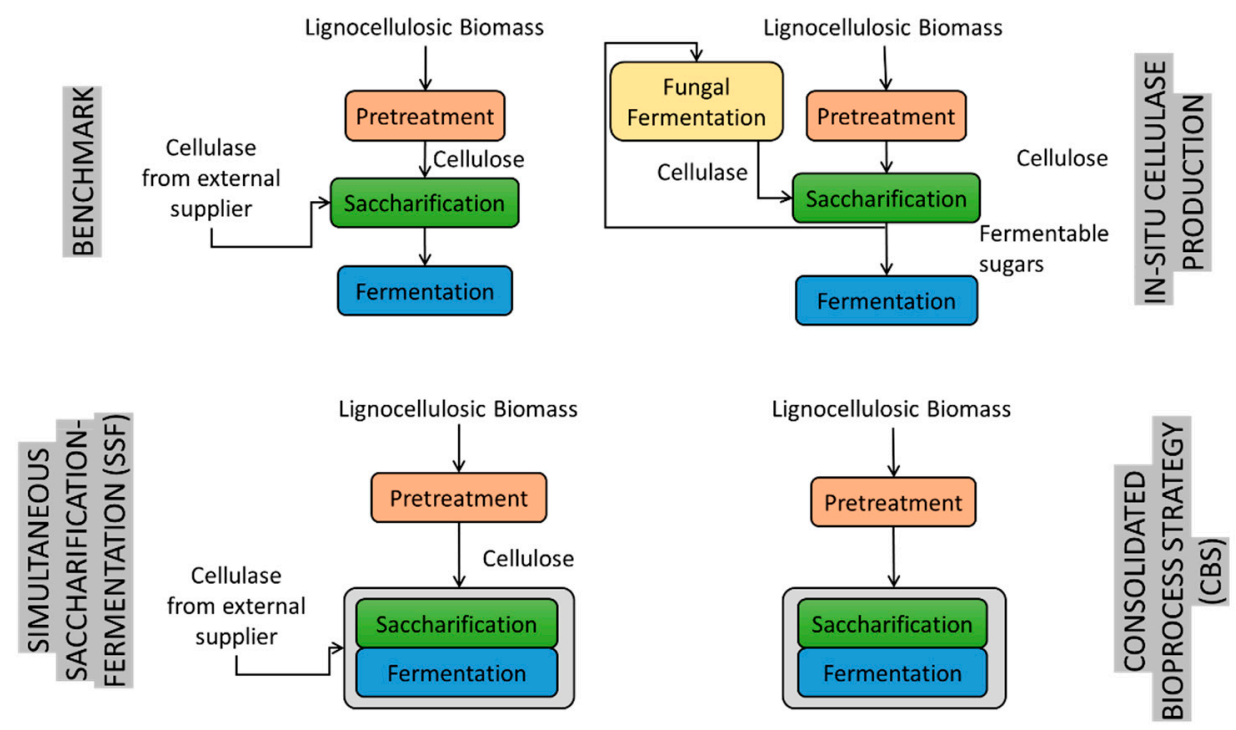

Figure 3. Strategies for lignocellulose saccharification and fermentation of lignocellulosic sugars $[9,37]$.

The production of cellulase embedded in the same biorefinery plants has been pursued, especially when the scale economy allows advantages. The economic advantage of implementing this process strategy in case of an ethanol plant has been demonstrated and it allowed a decrease of at least $10 \%$ of the production cost $[23,31,36]$. The integration of the pretreatment and hydrolysis operations was recently reported as an option to reduce unit operations and, thus, save costs. Novel solvents such as Ionic Liquid (IL) and 
Deep-Eutectic Solvents (DES) can be used together with cellulase [38,39], since, differently from other pretreatment techniques, DES pre-treatment does not require very harsh conditions in terms of temperature $[40,41]$; therefore, it allows the performance of one-pot pretreatment and enzymatic hydrolysis. Some disadvantages may be due to increased viscosity of the slurry. However, the stability and activity of cellulase must be tested for any kind of selected green solvent [38,42-45]. An alternative strategy of integration is based on simultaneous saccharification and fermentation (SSF). This option can be pursued by supplying cellulase and the pretreated lignocellulose biomass directly to the fermentation unit $[24,46]$. Disadvantages are related to the difference in optimal temperatures of the cellulose hydrolysis and sugar fermentation processes. Therefore, whenever SSF occurs, a compromise is required and, often, the kinetics of the cellulose hydrolysis is lowered.

The combination of cellulase production, cellulose hydrolysis and sugar fermentation into a one-pot process is called a "consolidated bioprocess" strategy $[2,11,37,47-50]$. This strategy is made possible by a microorganism community that exhibits a cellulolytic activity that is able to hydrolyse glycosylic bonds of the cellulose and to use the lignocellulosic sugars for further fermentation into valuable products. Two strategies are pursued in the literature in cases in which the original fermentative strain does not spontaneously exhibit cellulolytic activity: heterologous expression via metabolic engineering or implementation of a co(mmunity)-fermentation. However, it has to be stressed that, in both cases, a fraction of the lignocellulosic feedstock is metabolically sacrificed in the production of cellulase [9]. Several issues have to be tackled to make the consolidated bioprocess effective: (i) the biomass pretreatment must be suitable to allow the in situ production of cellulase; (ii) the cellulase production, hydrolysis and fermentation can run stepwise or simultaneously, varying the type and supply mode of the medium; (iii) hydrolysis rate inhibition due to the cellobiose is hard to control; and (iv) high solid loading is necessary to provide high sugar concentration at the fermentation step [11,37,48,51,52]. In particular, Lynd et al. [48] estimated that adding up cellulase production to the SSF cost, the ethanol production from lignocellulose biomass reached 0.06 Euro $/ \mathrm{kg}$, whereas the CBS can potentially reduce the cost by 4.5 times, down to 0.014 Euro $/ \mathrm{kg}$. When considering the entire economics of the process (including feedstock cost, pretreatment and downstream), the ethanol cost decreases from 0.24 Euro $/ \mathrm{kg}$ down to 0.19 Euro $/ \mathrm{kg}$. Although the difference of just six cents per $\mathrm{kg}$ of gasoline equivalent can seem quite insignificant over the course of the entire process, it is, nevertheless, particularly important for fuel production with its low manufacturing margins and price-driven competitive markets.

In our opinion, the large efforts reported to characterize cellulase kinetics and the overall rate of sugar production from real lignocellulosic substrates can be effectively applied to maximize yield and reduce costs of the sugar-based biorefinery if the saccharification of biomass is included as a separate first step in the process scheme. For this reason, it is worth analyzing the most relevant reactor configurations proposed so far for such enzymatic processes, as discussed in the next section.

\section{Bioreactor Design}

The benchmark technology allows a solid-liquid reaction step performed batch wise in stirred vessels at an optimised temperature, sacrificing the enzyme at each batch. Since the main cost of the enzymatic hydrolysis lays in the cost of the cellulolytic enzyme cocktail $[9,28,29,31,53]$, the continuous operation has also been investigated together with strategies for enzyme recycling. This aims, in theory, at significantly reducing the net loading of fresh enzyme per unit of cellulose below $20 \mathrm{mg} / \mathrm{g}$.

Recently, three main novel strategies have been proposed in the literature to reduce the use of the enzymes, classified as follows (Figure 4): (1) membrane reactors; (2) cellulase immobilization; and (3) novel configuration of continuous enzymatic hydrolysis process. 


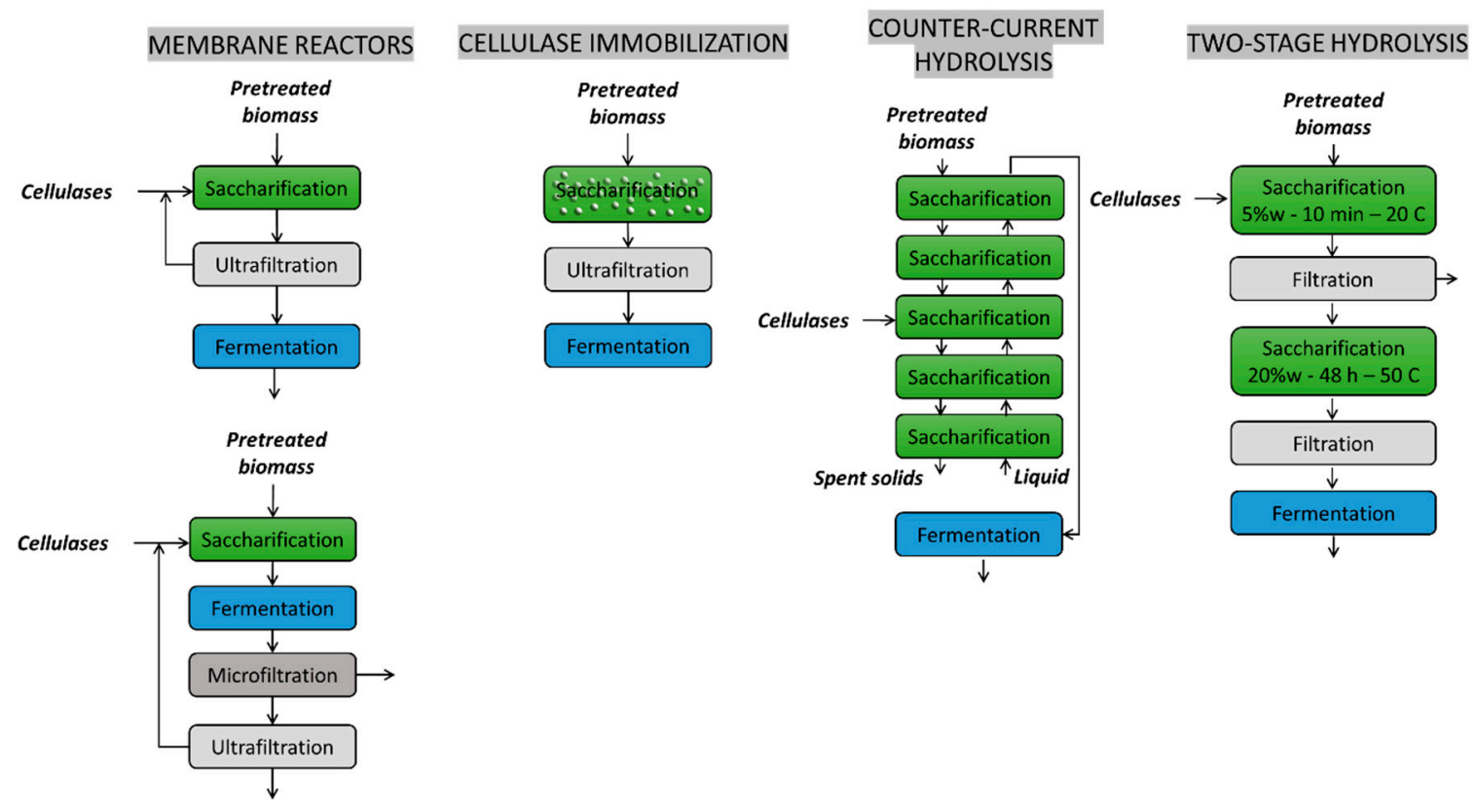

Figure 4. Novel bioreactor configurations for enzymatic hydrolysis.

Membrane reactors. The recycling of cellulase has become the main priority, together with the above-mentioned process integration [54], to make the process economically feasible. The retention of cellulase using membrane filtration has been the first attempt proposed in the literature to operate the hydrolysis continuously, to decouple the residence time of the substrate (the cellulose) from the residence time of the biocatalyst, and to prevent enzyme inhibition by the products (cellobiose and glucose) [11,55-57]. Several operational modes have been tested: batch, fed-batch, and continuous cellulose hydrolysis with intermittent or continuous product removal [22,58-61]. Chen et al. [60] proposed the use of electro-ultrafiltration to reduce the concentration polarization and increase the membrane flux. Gomes et al. [62] have, instead, analysed the possibility of recycling the cellulase by using membrane ultrafiltration after the fermentation.

The main problem when pursuing enzyme retention via the membrane is that the reaction occurs in a solid-liquid system, which makes it very difficult to operate cross-flow filtration over the membrane. To prevent membrane fouling, a pre-filtration step is placed after fermentation, where residual solid components from the fermentation are separated (residual cellulose, lignin, ashes and yeast cells).

In summary, two main advantages have been obtained with the use of membranebased recovery of the biocatalyst: (i) increased reaction rate due to the retention of the cellulases and the relief from product inhibition; (ii) reduced biocatalyst cost due to the re-use of the enzyme. Andric at al. [63] pointed out that these advantages did not sufficiently balance the disadvantages related to membrane use: (i) membrane fouling due to the residual accumulation of a high molecular weight unconvertible fraction; (ii) low sugar concentration in the outlet due to the necessity of operating at high dilution to prevent membrane fouling and to rapidly discharge inhibiting products; and (iii) low scalability of the membrane bioreactor to face the large throughput that is typical of large biorefinery plants.

Cellulase immobilization. More sophisticated approaches to enzyme retention have been investigated by immobilizing the enzyme on specific supports such as nanofibers, nanoparticles and organic metal frames. Sillu et al. [64] proposed the immobilization of cellulase on magnetic halloysite nanotubes. Driven by the potential ease of the recovery, the use of magnetic CLEA (Cross Linked Enzyme Aggregates) of cellulase for the hydrolysis of cellulose has been successfully reported at lab scale by several contributions [65-67]. It is worth mentioning a further advantage made possible by the immobilization of cellulase as a 
method to improve its stability to the exposition of ionic-liquid pretreated biomass [68-70]. Abraham et al. [71] and Cherian et al. [72] have surveyed the supports and techniques adopted for the immobilization of cellulose so far. Both research groups identified that the main drawbacks of immobilization are: (1) the cost of the technique; (2) the reliability at large scale; and (3) the long-term stability of the enzyme when immobilised. However, above all these, cellulose immobilization may be not a winning strategy due to the intrinsic nature of the heterogeneous process: in the case of real lignocellulosic biomass saccharification, the solid substrate can be converted by the enzymes upon their adsorption on the substrate surface. The adsorption and complexation of an immobilised enzyme over a solid substrate surface may be even more difficult than that of a free enzyme.

Novel configuration of continuous enzymatic hydrolysis process. Effective optimization of the enzymatic hydrolysis step has been achieved by several operational strategies using conventional stirred reactors with free enzymes. Counter-current saccharification has been applied to overcome the problem of product inhibition that typically affects the cellulase catalysis (see Section 2) [73] and the loss of efficiency during the process due to the lowering of biomass reactivity as conversion increases [4,74]. The optimised operation is characterized by an efficient use of the enzyme, allowing a reduction in the enzyme loading of 8-20 times compared to the conventional mode [75,76]. Counter-current saccharification has been successfully applied to a model substrate ( $\alpha$-cellulose), and it is worth investigating its effect on real biomass samples.

The effect of solids loading has been also addressed through effective tuning of this operational parameter. Typically, $5 \%$ wt solids loading promotes mixing and efficient adsorption of the enzymes on the biomass surface, but rarely provides sugar concentrations larger than $50 \mathrm{~g} / \mathrm{L}$. This low value of sugar concentration affects the performance of the fermentation [3]. Concentration of sugar hydrolysate by evaporation is not an option due to the high energy and equipment costs. Hence, some attempts have been reported in the literature to perform the hydrolysis at larger solids loading $(20-35 \% \mathrm{wt})$ [3]. Under these conditions, the mixing is very hard, and a low rate of hydrolysis is reported due to a penalised adsorption of the biocatalyst on the substrate surface. Therefore, a two-stage strategy has been proposed by Xue et al. [77] and Gonzalez-Quiroga et al. [78]. The cellulase enzymes are mixed with the pretreated biomass at $5 \%$ wt solids loading for few minutes at low temperature, then the slurry is concentrated up to $20 \% \mathrm{wt}$ solids by filtration and the temperature is increased up to $50^{\circ} \mathrm{C}$, and hydrolysis takes place. The percolated liquid is recycled back to the enzyme adsorption unit. In this way, the enzymes adsorption takes place in a few minutes, at low biomass loading, so that the biomass reaches high levels of adsorbed enzymes. Slurry filtration allows the increasing of solids loading up to values that promote high sugar concentrations in the liquid during the hydrolysis. In comparison with a direct supplementation of the enzyme at $20 \%$ solids loading, sugar concentration increased from 26 to $121 \mathrm{~g} / \mathrm{L}$ with an almost constant cellulose conversion degree of $63 \%$. A further improvement of this scheme involves a split addition of the enzymes: cellulases are added to the adsorption stage (at $5 \% \mathrm{wt}$ solids loading) and the further enzymes ( $\beta$ glucosidase and hemicellulase) are supplemented step-wise to the hydrolysis stage (at $20 \%$ wt solids loading) [77]. The sequential adsorption/hydrolysis configuration has been modelled by Gonzalez-Quiroga et al. [78], proving its effectiveness in both a series of CSTR and a train of fed-batch reactors. Tubular reactors (PFR) or series of stirred reactors (CSTR) have been found to be more effective because their use can limit the product inhibition over the cellulase $[28,53]$.

\section{Enzymatic Pretreatment of Lignocellulosic Biomass: Laccase Catalyzed Delignification}

The use of enzymes in biorefinery processes has been predominantly applied to recover soluble sugars from the polysaccharide fraction of biomasses. As mentioned in the previous section, access of hydrolytic enzymes to cellulose and hemicellulose chains is possible if the biomass structure is modified through effective depolymerization of lignin. The pretreatments developed so far achieved this objective by unspecific mechanical, 
physical or chemical deconstruction and lignin modification $[79,80]$. The structure of lignin is composed of phenolic monomers (monolignols), and most of the pretreatments acting on the whole biomass can lead to the undesired formation of byproducts from the depolymerization of lignin and polysaccharides (e.g., hydroxymethyl furfural).

In nature, several microorganisms can access lignocellulosic sugars through their ability to degrade lignin by specific enzyme cocktails, including laccases and peroxidases [8]. Deep knowledge on microbial ligninolytic activity inspired research efforts aimed at the use of laccases as a biocatalyst for industrial delignification processes for biorefinery purposes. The development of this process can allow a fully enzymatic saccharification of biomass catalyzed by a cascade enzymatic process involving laccases and cellulase.

The development of lignin degradation as an industrial process begins with the pulp and paper industry and, as a traditional process encased in a horizontal economy, did not draw attention to the fate of lignin as a carbon-based byproduct. Current efforts in developing biorefinery processes are aimed at maximizing yield of sugars from biomass depolymerization and to recover, as much as possible, valuable compounds from the not-fermentable fraction of the feedstock, including lignin. In addition, saving costs and avoiding the use of solvents are among the primary requirements in a green and circular economy framework. Roth and Spiess [8] reported a list of review studies on laccases (benzenediol-oxygen-oxidoreductase, EC 1.10.3.2), knowledge of which dates back to the 19th century. Fungal laccases are among the types of oxidoreductase with the largest redox potential and use only oxygen as an electron acceptor in the oxidation of phenols. The formation of radicals from laccase catalyzed oxidation makes these enzymes active, both in lignin biosynthesis and in lignin degradation, by plants and wood-degrading basidiomycetes, respectively. In some cases, mediator molecules can take part in the laccase catalyzed reaction, acting as an electron shuttle in the laccase mediator system (LMS). This role opens numbers of opportunities for industrial application, and it could also be helpful in the development of lignin degrading applications due to the more effective diffusion of mediator molecules into the heterogeneous lignocellulosic structure being the final target of the oxidation process [81,82]. Two strategies were proposed for the development of this process: (i) the application of laccase catalysis as the only delignification process or as a secondary pretreatment after a chemical or physical step; (ii) the combined use of laccases and cellulases in a one-pot or in a stepwise enzyme cascade conversion of biomass. These strategies are applied to the schemes proposed in Figure 5 as possible implementations of the enzymatic delignification.

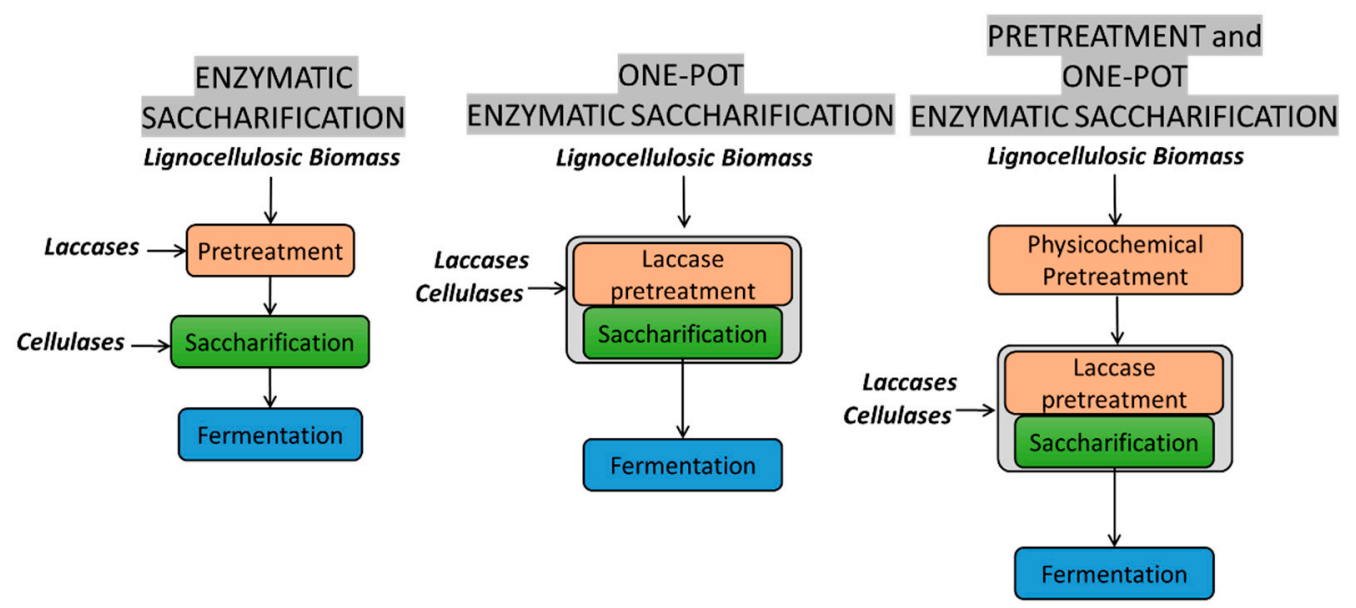

Figure 5. Block diagrams for alternative pretreatment/hydrolysis processes based on the use of laccase for delignification.

Laccase action leads to a chemical modification of the lignin with almost no removal of lignin from the whole biomass (e.g., oxidation of hydroxyl group to ketone). Indeed, Niglio et al. [83], during the pretreatment of apple pomace with laccase, observed: a 
slight reduction in the lignin content and an increase in the sugar yield when biomass was pretreated with laccases. Lignin modifications influence the superficial properties of lignin and its ability to adsorb proteins [84]. Unproductive adsorption of cellulases on lignin is among the phenomena that most affect the overall activity of cellulases in the heterogeneous process of biomass saccharification. Therefore, two considerations hold: (i) laccase action on raw biomass is worth assessing to verify its indirect effect on the successive polysaccharide hydrolysis catalysed by cellulose; (ii) one-pot laccase-cellulase catalysis may not be effective because the extent of lignin modification that favors cellulase productive adsorption can hardly be optimized.

As regards point (i), laccase catalysis provides a modified residual lignin that may be removed from the solid substrate more easily than the original lignin by physicochemical treatments $[85,86]$. This strategy is consistent with sequential use of laccases and physico-chemical processes but could not be combined with one-pot laccase-cellulase biocatalytic process.

Point (ii) asks for careful analysis of technical solutions enabling one-pot processes and, thus, promoting cost saving. It is well known that cellulase activity is dumped by laccases [87]. Therefore, stepwise strategies have been tested to overcome this phenomenon. An effective sequential use of laccases and the cocktail of cellulases in the saccharification of brewery spent grains [88] was made possible by the thermal deactivation of laccases after the delignification step. Similarly, Niglio et al. [83] applied this technique in the saccharification of apple pomace in a bench-scale bubble column reactor. This approach can be further enhanced if effective immobilization techniques could be applied for controlled supplementation and removal of laccases from the reactors [89]. According to this strategy, both solvent and enzyme saving will beneficially affect the overall cost of the operation. The extensive review by Roth and Spiess [8] lists guidelines for the design of lignin depolymerization catalyzed by laccase. The most relevant guidelines for the topic of bioreactor design concern the handling of mediators and of lignin oxidation products. Bioreactor design can indeed offer technical solutions to manage multi-step/cascade reactions. The operation of reactors under continuous conditions may help to overcome problems that arise due to the deactivation of laccases in the presence of mediators, and the occurrence of repolymerization. In particular, the removal of produced radicals and quinones during lignin depolymerization makes it possible to avoid repolymerization and can be efficiently performed by continuous bioreactors. Steinmetz et al. [90] have recently proved the effective use of a lab scale membrane reactor in the depolymerization of soluble lignin recovered from a thermomechanical pulping process with commercial laccases (Novozym 51003) from Aspergillus sp. The in-situ filtration of the low molecular weight fraction from the reaction media avoids repolymerization, which typically occurs in the batch experiments without filtration. This finding highlights how the process and reactor design are fundamental, even at the early stages of biocatalytic process development.

In most of the enzyme catalysis applications, enzyme immobilization can solve problems related to biocatalyst deactivation and it allows enzyme reuse with cost saving. In the case of laccase catalyzed pretreatment of biomass, the work by Shanmugam et al. [89] proposed an effective strategy for laccase immobilization on $\mathrm{Fe}_{3} \mathrm{O}_{4} @ \mathrm{SiO}_{2}$ nanoparticles coated with chitosan. The authors showed effective performance of the immobilized enzyme on real biomass samples of sweet sorghum stover by recovering and reusing the magnetic biocatalysts for eight cycles.

\section{Conclusions and Future Perspectives}

The present review highlights most recent remarkable findings in the development of processes and technologies for the enzymatic saccharification of lignocellulosic biomasses. This fundamental step in the transformation of lignocellulose into sugars to be converted into added-value chemicals and fuels is currently made possible by the combination of physico-chemical pretreatments (delignification) and enzymatic hydrolysis of biomass from dedicated cultures or waste and residues. The main bottlenecks are (1) the slow 
kinetic due to both the solid-liquid reaction mechanism and the low intrinsic kinetic of the cellulase, (2) the high cost of the enzyme and (3) the need for a pretreatment. This makes the material and equipment cost of the operation significant for the entire process. The performance of the enzymatic saccharification operation can be improved with respect to the current state of the art if (A) proper strategies for enzyme reuse, (B) maximization of biomass conversion, and (C) process integration strategies are implemented. The rational design of bioreactors should be based on the knowledge of the main phenomena affecting the heterogeneous process involving cellulases, $\beta$-glucosidases and solid multicomponent substrates made by real biomasses. Among these phenomena, enzyme adsorption on the biomass fiber's surface, and product inhibition, should be carefully considered in bioreactor design and operation. Promising configurations proposed so far include countercurrent hydrolysis reactors-the split addition of the enzyme component of the biocatalytic cocktails, with careful tuning of conditions for the maximization of adsorbed enzyme loading, in the early stage of the process-and enzyme retention by membrane or immobilization. While the first approach only involves a change of the operating condition and flow pattern of the phases in the bioreactor, the second one requires the development of a new robust technology at an industrial scale for the enzyme retention and recycling. However, none of these technologies have been validated at a relevant industrial scale by a reliable cost-benefit analysis.

Innovative solutions for process integration that, in the future, may provide an increase in the sustainability of saccharification processes can also be obtained through the development of laccase catalyzed delignification of biomasses. This approach seems more promising than either the enzyme retention, which is still technically limited, or the process integration by SSF or CBS, which is limited by the intrinsic performance of the strain when undertaking several steps in one operation. Coupling delignification with enzymatic hydrolysis allows a fully enzymatic conversion of lignocellulose into sugars and solid residues that is almost free of solvents. In this framework, basic knowledge on lignin chemical modification and depolymerization catalyzed by laccases and laccases-mediator systems is sufficiently large and sound to select those issues that should be addressed when developing industrial processes and designing reactor units. To this end, particularly promising strategies are: to combine or to stepwise operate the enzymatic catalytic steps of delignification and polysaccharides hydrolysis; the removal of lignin degradation products from the reacting system to avoid repolymerization phenomena; the proper selection of laccase mediators (if necessary); and the possibility to reuse enzymes by means of immobilization techniques.

Author Contributions: Conceptualization, M.E.R. and G.O.; formal analysis, M.E.R. and G.O.; data curation, M.E.R. and G.O.; writing-original draft preparation, M.E.R., G.O., R.H.W. and A.M.; writing-review and editing, M.E.R., G.O., R.H.W. and A.M. All authors have read and agreed to the published version of the manuscript.

Funding: This research received no external funding.

Conflicts of Interest: The authors declare no conflict of interest.

\section{References}

1. Østby, H.; Hansen, L.D.; Horn, S.J.; Eijsink, V.G.H.; Várnai, A. Enzymatic processing of lignocellulosic biomass: Principles, recent advances and perspectives. J. Ind. Microbiol. Biotechnol. 2020, 47, 623-657. [CrossRef] [PubMed]

2. Brethauer, S.; Wyman, C.E. Review: Continuous hydrolysis and fermentation for cellulosic ethanol production. Bioresour. Technol. 2010, 101, 4862-4874. [CrossRef]

3. Modenbach, A.A.; Nokes, S.E. Enzymatic hydrolysis of biomass at high-solids loadings: A review. Biomass Bioenergy 2013, 56, 526-544. [CrossRef]

4. Tsegaye, B.; Balomajumder, C.; Roy, P. Microbial delignification and hydrolysis of lignocellulosic biomass to enhance biofuel production: An overview and future prospect. Bull. Natl. Res. Cent. 2019, 43, 51. [CrossRef]

5. Galbe, M.; Zacchi, G. Pretreatment of Lignocellulosic Materials for Efficient Bioethanol Production. Blue Biotechnol. 2007, 108, 41-65. [CrossRef]

6. EUBIA. WikiBiomass. Available online: https://www.eubia.org/cms/wiki-biomass (accessed on 23 May 2021). 
7. Sheng, Y.; Lam, S.S.; Wu, Y.; Ge, S.; Wu, J.; Cai, L.; Huang, Z.; Van Le, Q.; Sonne, C.; Xia, C. Enzymatic conversion of pretreated lignocellulosic biomass: A review on influence of structural changes of lignin. Bioresour. Technol. 2021, 324, 124631. [CrossRef] [PubMed]

8. Roth, S.; Spiess, A.C. Laccases for biorefinery applications: A critical review on challenges and perspectives. Bioprocess Biosyst. Eng. 2015, 38, 2285-2313. [CrossRef] [PubMed]

9. Lynd, L.R.; Weimer, P.J.; Van Zyl, W.H.; Pretorius, I.S. Microbial Cellulose Utilization: Fundamentals and Biotechnology. Microbiol. Mol. Biol. Rev. MMBT 2002, 66, 506-577. [CrossRef]

10. Bansal, P.; Hall, M.; Realff, M.J.; Lee, J.H.; Bommarius, A.S. Modeling cellulase kinetics on lignocellulosic substrates. Biotechnol. Adv. 2009, 27, 833-848. [CrossRef]

11. Olson, D.G.; E McBride, J.; Shaw, A.J.; Lynd, L.R. Recent progress in consolidated bioprocessing. Curr. Opin. Biotechnol. 2012, $23,396-405$. [CrossRef]

12. Ferreira, R.; Azzoni, A.R.; Freitas, S. On the production cost of lignocellulose-degrading enzymes. Biofuels Bioprod. Biorefining 2021, 15, 85-99. [CrossRef]

13. Jeoh, T.; Cardona, M.J.; Karuna, N.; Mudinoor, A.R.; Nill, J. Mechanistic kinetic models of enzymatic cellulose hydrolysis-A review. Biotechnol. Bioeng. 2017, 114, 1369-1385. [CrossRef] [PubMed]

14. Gusakov, A.; Sinitsyn, A.; Klyosov, A. Kinetics of the enzymatic hydrolysis of cellulose: 1 . A mathematical model for a batch reactor process. Enzym. Microb. Technol. 1985, 7, 346-352. [CrossRef]

15. Gusakov, A.; Sinitsyn, A.; Klyosov, A. Kinetics of the enzymatic hydrolysis of cellulose: 2. A mathematical model for the process in a plug-flow column reactor. Enzym. Microb. Technol. 1985, 7, 383-388. [CrossRef]

16. Drissen, R.E.T.; Maas, R.H.W.; Van Der Maarel, M.J.E.C.; Kabel, M.A.; Schols, H.A.; Tramper, J.; Beeftink, H.H. A generic model for glucose production from various cellulose sources by a commercial cellulase complex. Biocatal. Biotransform. 2007, 25, 419-429. [CrossRef]

17. Chrastil, J. Enzymic product formation curves with the normal or diffusion limited reaction mechanism and in the presence of substrate receptors. Int. J. Biochem. 1988, 20, 683-693. [CrossRef]

18. Pratto, B.; Alencar de Souza, R.B.; Sousa, R., Jr.; Gonçalves da Cruz, A.J. Enzymatic Hydrolysis of Pretreated Sugarcane Straw: Kinetic Study and Semi-Mechanistic Modeling. Appl. Biochem. Biotechnol. 2016, 178, 1430-1444. [CrossRef]

19. Procentese, A.; Russo, M.E.; Di Somma, I.; Marzocchella, A. Kinetic Characterization of Enzymatic Hydrolysis of Apple Pomace as Feedstock for a Sugar-Based Biorefinery. Energies 2020, 13, 1051. [CrossRef]

20. Sousa, R.S., Jr.; Carvalho, M.L.; Giordano, R.L.C. Recent trends in the modeling of cellulose hydrolysis. Braz. J. Chem. Eng. 2011, 28, 545-564. [CrossRef]

21. Gan, Q.; Allen, S.; Taylor, G. Kinetic dynamics in heterogeneous enzymatic hydrolysis of cellulose: An overview, an experimental study and mathematical modelling. Process. Biochem. 2003, 38, 1003-1018. [CrossRef]

22. Gan, Q.; Allen, S.; Taylor, G. Analysis of process integration and intensification of enzymatic cellulose hydrolysis in a membrane bioreactor. J. Chem. Technol. Biotechnol. 2005, 80, 688-698. [CrossRef]

23. Johnson, E. Integrated enzyme production lowers the cost of cellulosic ethanol. Biofuels Bioprod. Biorefining 2016, 10, 164-174. [CrossRef]

24. Liu, C.G.; Xiao, Y.; Xia, X.X.; Zhao, X.Q.; Peng, L.; Srinophakun, P.; Bai, F.W. Cellulosic ethanol production: Progress, challenges and strategies for solutions. Biotechnol. Adv. 2019, 37, 491-504. [CrossRef]

25. Lynd, L.R.; Laser, M.S.; Bransby, D.; E Dale, B.; Davison, B.; Hamilton, R.; Himmel, M.; Keller, M.; McMillan, J.D.; Sheehan, J.; et al. How biotech can transform biofuels. Nat. Biotechnol. 2008, 26, 169-172. [CrossRef]

26. Sinitsyn, A.P.; Sinitsyna, O.A. Bioconversion of Renewable Plant Biomass. Second-Generation Biofuels: Raw Materials, Biomass Pretreatment, Enzymes, Processes, and Cost Analysis. Biochemistry 2021, 86, S166-S195. [CrossRef]

27. Barta, Z.; Kovacs, K.; Reczey, K.; Zacchi, G. Process Design and Economics of On-Site Cellulase Production on Various Carbon Sources in a Softwood-Based Ethanol Plant. Enzym. Res. 2010, 2010, 1-8. [CrossRef]

28. Humbird, D.; Davis, R.; Tao, L.; Kinchin, C.; Hsu, D.; Aden, A. Process Design and Economics for Biochemical Conversion of Lignocellulosic Biomass to Ethanol: Dilute-Acid Pretreatment and Enzymatic Hydrolysis of Corn Stover; Technical Report NREL/TP5100-47764; National Renewable Energy Lab. (NREL): Golden, CO, USA, 2011.

29. Klein-Marcuschamer, D.; Oleskowicz-Popiel, P.; Simmons, B.A.; Blanch, H.W. The challenge of enzyme cost in the production of lignocellulosic biofuels. Biotechnol. Bioeng. 2012, 109, 1083-1087. [CrossRef]

30. Kumar, D.; Murthy, G.S. Impact of pretreatment and downstream processing technologies on economics and energy in cellulosic ethanol production. Biotechnol. Biofuels 2011, 4, 27. [CrossRef]

31. Davis, R.; Tao, L.; Tan, E.C.D.; Biddy, M.J.; Beckham, G.T.; Scarlata, C.; Jacobson, J.; Cafferty, K.; Ross, J.; Lukas, J.; et al. Process Design and Economics for the Conversion of Lignocellulosic Biomass to Hydrocarbons: Dilute-Acid and Enzymatic Deconstruction of Biomass to Sugars and Biological Conversion of Sugars to Hydrocarbons; National Renewable Energy Laboratory: Golden, CO, USA, 2013.

32. Taha, M.; Foda, M.; Shahsavari, E.; Aburto-Medina, A.; Adetutu, E.; Ball, A. Commercial feasibility of lignocellulose biodegradation: Possibilities and challenges. Curr. Opinion Biotechnol. 2016, 38, 190-197. [CrossRef]

33. Chandel, A.K.; Albarelli, J.Q.; Santos, D.T.; Chundawat, S.P.; Puri, M.; Meireles, M.A.A. Comparative analysis of key technologies for cellulosic ethanol production from Brazilian sugarcane bagasse at a commercial scale. Biofuels Bioprod. Biorefineries 2019, 13, 994-1014. [CrossRef] 
34. Bhati, N.; Shreya; Sharma, A.K. Cost-effective cellulase production, improvement strategies, and future challenges. J. Food Process. Eng. 2021, 44, 1-11. [CrossRef]

35. Behera, S.S.; Ray, R.C. Solid state fermentation for production of microbial cellulases: Recent advances and improvement strategies. Int. J. Biol. Macromol. 2016, 86, 656-669. [CrossRef]

36. Siqueira, J.G.W.; Rodrigues, C.; Vandenberghe, L.P.D.S.; Woiciechowski, A.L.; Soccol, C.R. Current advances in on-site cellulase production and application on lignocellulosic biomass conversion to biofuels: A review. Biomass Bioenergy 2020, 132, 105419. [CrossRef]

37. Liu, Y.J.; Li, B.; Feng, Y.; Cui, Q. Consolidated bio-saccharification: Leading lignocellulose bioconversion into the real world. Biotechnol. Adv. 2020, 40, 107535. [CrossRef] [PubMed]

38. Elgharbawy, A.A.; Alam, Z.; Moniruzzaman, M.; Goto, M. Ionic liquid pretreatment as emerging approaches for enhanced enzymatic hydrolysis of lignocellulosic biomass. Biochem. Eng. J. 2016, 109, 252-267. [CrossRef]

39. Bose, S.; Armstrong, D.W.; Petrich, J.W. Enzyme-Catalyzed Hydrolysis of Cellulose in Ionic Liquids: A Green Approach Toward the Production of Biofuels. J. Phys. Chem. B 2010, 114, 8221-8227. [CrossRef]

40. Procentese, A.; Raganati, F.; Olivieri, G.; Russo, M.E.; Rehmann, L.; Marzocchella, A. Low-energy biomass pretreatment with deep eutectic solvents for bio-butanol production. Bioresour. Technol. 2017, 243, 464-473. [CrossRef]

41. Procentese, A.; Raganati, F.; Olivieri, G.; Russo, M.E.; Rehmann, L.; Marzocchella, A. Deep Eutectic Solvents pretreatment of agro-industrial food waste. Biotechnol. Biofuels 2018, 11, 1-12. [CrossRef]

42. Wahlström, R.M.; Suurnakki, A. Enzymatic hydrolysis of lignocellulosic polysaccharides in the presence of ionic liquids. Green Chem. 2015, 17, 694-714. [CrossRef]

43. Gunny, A.A.N.; Arbain, D.; Gumba, E.R.; Jong, B.C.; Jamal, P. Potential halophilic cellulases for in situ enzymatic saccharification of ionic liquids pretreated lignocelluloses. Biores. Technol. 2014, 155, 177-181. [CrossRef]

44. Gunny, A.A.N.; Arbain, D.; Nashef, E.M.; Jamal, P. Applicability evaluation of Deep Eutectic Solvents-Cellulase system for lignocellulose hydrolysis. Bioresour. Technol. 2015, 181, 297-302. [CrossRef]

45. Gunny, A.A.N.; Arbain, D.; Javed, M.; Baghaei-Yazdi, N.; Gopinath, S.C.; Jamal, P. Deep eutectic solvents-halophilic cellulase system: An efficient route for in situ saccharification of lignocellulose. Process. Biochem. 2019, 81, 99-103. [CrossRef]

46. Guo, Z.; Ling, Z.; Wang, C.; Zhang, X.; Xu, F. Integration of facile deep eutectic solvents pretreatment for enhanced enzymatic hydrolysis and lignin valorization from industrial xylose residue. Biores. Technol. 2018, 265, 334-339. [CrossRef]

47. Carere, C.R.; Sparling, R.; Cicek, N.; Levin, D.B. Third Generation Biofuels via Direct Cellulose Fermentation. Int. J. Mol. Sci. 2008, 9, 1342-1360. [CrossRef]

48. Lynd, L.R.; Van Zyl, W.H.; E McBride, J.; Laser, M. Consolidated bioprocessing of cellulosic biomass: An update. Curr. Opin. Biotechnol. 2005, 16, 577-583. [CrossRef] [PubMed]

49. Liu, S.; Liu, Y.J.; Feng, Y.; Li, B.; Cui, Q. Construction of consolidated bio-saccharification biocatalyst and process optimization for highly efficient lignocellulose solubilization. Biotechnol. Biofuels 2019, 12, 1-12. [CrossRef] [PubMed]

50. Ali, N.; Zhang, Q.; Liu, Z.Y.; Li, F.L.; Lu, M.; Fang, X.C. Emerging technologies for the pretreatment of lignocellulosic materials for bio-based products. Appl. Microbiol. Biotechnol. 2020, 104, 455-473. [CrossRef] [PubMed]

51. Hasunuma, T.; Okazaki, F.; Okai, N.; Hara, K.Y.; Ishii, J.; Kondo, A. A review of enzymes and microbes for lignocellulosic biorefinery and the possibility of their application to consolidated bioprocessing technology. Bioresour. Technol. 2013, 135, 513-522 [CrossRef]

52. Xin, F.; Dong, W.; Zhang, W.; Ma, J.; Jiang, M. Biobutanol Production from Crystalline Cellulose through Consolidated Bioprocessing. Trends Biotechnol. 2019, 37, 167-180. [CrossRef]

53. Aden, A.; Ruth, M.; Ibsen, K.; Jechura, J.; Neeves, K.; Sheehan, J.; Wallace, B.; Montague, L.; Slayton, A.; Lukas, J. Lignocellulosic Biomass to Ethanol Process Design and Economics Utilizing Co-Current Dilute Acid Prehydrolysis and Enzymatic Hydrolysis for Corn Stover; Technical Report NREL/TP-510-32438; National Renewable Energy Laboratory: Golden, CO, USA, 2002.

54. Jørgensen, H.; Pinelo, M. Enzyme recycling in lignocellulosic biorefineries. Biofuels Bioprod. Biorefining 2017, 11, 150-167. [CrossRef]

55. Alfani, F.; Albanesi, D.; Cantarella, M.; Scardi, V.; Vetromile, A. Kinetics of enzymatic saccharification of cellulose in a flatmembrane reactor. Biomass 1982, 2, 245-253. [CrossRef]

56. Kinoshita, S.; Chua, J.W.; Kato, N.; Yoshida, T.; Taguchi, H. Hydrolysis of cellulose by cellulases of Sporotrichum cellulophilum in an ultrafilter membrane reactor. Enzym. Microb. Technol. 1986, 8, 691-695. [CrossRef]

57. Hong, J.; Tsao, G.T.; Wankat, P.C. Membrane reactor for enzymatic hydrolysis of cellobiose. Biotechnol. Bioeng. 1981, 23, 1501-1506. [CrossRef]

58. Gan, Q.; Allen, S.; Taylor, G. Design and operation of an integrated membrane reactor for enzymatic cellulose hydrolysis. Biochem. Eng. J. 2002, 12, 223-229. [CrossRef]

59. Al-Zuhair, S.; Al-Hosany, M.; Zooba, Y.; Al-Hammadi, A.; Al-Kaabi, S. Development of a membrane bioreactor for enzymatic hydrolysis of cellulose. Renew. Energy 2013, 56, 85-89. [CrossRef]

60. Chen, G.; Song, W.; Qi, B.; Lu, J.; Wan, Y. Recycling cellulase from enzymatic hydrolyzate of acid treated wheat straw by electroultrafiltration. Bioresour. Technol. 2013, 144, 186-193. [CrossRef] [PubMed]

61. Shokrkar, H.; Ebrahimi, S.; Zamani, M. A review of bioreactor technology used for enzymatic hydrolysis of cellulosic materials. Cellulose 2018, 25, 6279-6304. [CrossRef] 
62. Gomes, D.G.; Serna-Loaiza, S.; Cardona, C.A.; Gama, M.; Domingues, L. Insights into the economic viability of cellulases recycling on bioethanol production from recycled paper sludge. Bioresour. Technol. 2018, 267, 347-355. [CrossRef]

63. Andrić, P.; Meyer, A.S.; Jensen, P.A.; Dam-Johansen, K. Reactor design for minimizing product inhibition during enzymatic lignocellulose hydrolysis: II. Quantification of inhibition and suitability of membrane reactors. Biotechnol. Adv. 2010, 28, 407-425. [CrossRef]

64. Sillu, D.; Agnihotri, S. Cellulase Immobilization onto Magnetic Halloysite Nanotubes: Enhanced Enzyme Activity and Stability with High Cellulose Saccharification. ACS Sustain. Chem. Eng. 2020, 8, 900-913. [CrossRef]

65. Nguyen, L.T.; Neo, K.R.S.; Yang, K.-L. Continuous hydrolysis of carboxymethyl cellulose with cellulase aggregates trapped inside membranes. Enzym. Microb. Technol. 2015, 78, 34-39. [CrossRef]

66. Hwangbo, M.; Tran, J.L.; Chu, K.H. Effective one-step saccharification of lignocellulosic biomass using magnet-ite-biocatalysts containing saccharifying enzymes. Sc. Total Environ. 2019, 647, 806-813. [CrossRef]

67. Dong, R.; Zheng, D.; Yang, D.; Qiu, X. pH-responsive lignin-based magnetic nanoparticles for recovery of cellulase. Bioresour. Technol. 2019, 294, 122133. [CrossRef]

68. Zhou, Z.; Ju, X.; Zhou, M.; Xu, X.; Fu, J.; Li, L. An enhanced ionic liquid-tolerant immobilized cellulase system via hydrogel microsphere for improving in situ saccharification of biomass. Bioresour. Technol. 2019, 294, 122146. [CrossRef]

69. Zhou, M.; Ju, X.; Li, L.; Yan, L.; Xu, X.; Chen, J. Immobilization of cellulase in the non-natural ionic liquid environments to enhance cellulase activity and functional stability. Appl. Microbiol. Biotechnol. 2019, 103, 2483-2492. [CrossRef]

70. Zhou, M.J.X.; Zhou, Z.; Yan, L.; Chen, J.; Yao, X.; Xu, X.; Li, L.Z. Development of an Immobilized Cellulase System Based on Metal-Organic Frameworks for Improving Ionic Liquid Tolerance and In Situ Saccharification of Bagasse. ACS Sustain. Chem. Eng. 2019, 7, 19185-19193. [CrossRef]

71. Abraham, R.E.; Puri, M. Nano-immobilized cellulases for biomass processing with application in biofuel production. Methods Enzymol. 2020, 630, 327-346. [CrossRef]

72. Cherian, E.; Baskar, G.G. Immobilized Biocatalysts in Bioethanol Production: Scale-up Opportunities for Commercialization. In Horizons in Bioprocess. Engineering 2021; Pogaku, R., Ed.; Springer Nature: Basingstoke, UK, 2019.

73. Andrić, P.; Meyer, A.S.; Jensen, P.A.; Dam-Johansen, K. Reactor design for minimizing product inhibition during enzymatic lignocellulose hydrolysis: I. Significance and mechanism of cellobiose and glucose inhibition on cellulolytic enzymes. Biotechnol. Adv. 2010, 28, 308-324. [CrossRef]

74. Yang, B.; Willies, D.M.; Wyman, C.E. Changes in the Enzymatic Hydrolysis Rate of Avicel Cellulose with Conversion. Biotechnol. Bioeng. 2006, 94, 1122-1128. [CrossRef] [PubMed]

75. Zentay, A.N.; Liang, C.; Lonkar, S.; Holtzapple, M.T. Countercurrent enzymatic saccharification of cellulosic biomass. Biomass Bioenergy 2016, 90, 122-130. [CrossRef]

76. Liang, C.; Gu, C.; Karim, M.N.; Holtzapple, M. Kinetic modeling of countercurrent saccharification. Biotechnol. Biofuels 2019, 12, 1-13. [CrossRef] [PubMed]

77. Xue, Y.; Jameel, H.; Phillips, R.; Chang, H.-M. Split addition of enzymes in enzymatic hydrolysis at high solids concentration to increase sugar concentration for bioethanol production. J. Ind. Eng. Chem. 2012, 18, 707-714. [CrossRef]

78. Quiroga, A.G.; Silvera, A.B.; Padilla, R.V.; Da Costa, A.C.; Filho, R.M. Continuous and semicontinuous reaction systems for high-solids enzymatic hydrolysis of lignocellulosics. Braz. J. Chem. Eng. 2015, 32, 805-819. [CrossRef]

79. Alvira, P.; Tomás-Pejó, E.; Ballesteros, M.; Negro, M. Pretreatment technologies for an efficient bioethanol production process based on enzymatic hydrolysis: A review. Bioresour. Technol. 2010, 101, 4851-4861. [CrossRef]

80. Narron, R.H.; Kim, H.; Chang, H.-M.; Jameel, H.; Park, S. Biomass pretreatments capable of enabling lignin valorization in a biorefinery process. Curr. Opin. Biotechnol. 2016, 38, 39-46. [CrossRef]

81. Crestini, C.; Argyropoulos, D.S. The early oxidative biodegradation steps of residual kraft lignin models with laccase. Bioorg. Med. Chem. 1998, 6, 2161-2169. [CrossRef]

82. Barreca, A.M.; Fabbrini, M.; Galli, C.; Gentili, P.; Ljunggren, S. Laccase/mediated oxidation of a lignin model for improved delignification procedures. J. Mol. Catal. B Enzym. 2003, 26, 105-110. [CrossRef]

83. Niglio, S.; Procentese, A.; Russo, M.E.; Piscitelli, A.; Marzocchella, A. Integrated enzymatic pretreatment and hydrolysis of apple pomace in a bubble column bioreactor. Biochem. Eng. J. 2019, 150, 107306. [CrossRef]

84. Moilanen, U.; Kellock, M.; Várnai, A.; Andberg, M.; Viikari, L. Mechanisms of laccase-mediator treatments improving the enzymatic hydrolysis of pre-treated spruce. Biotechnol. Biofuels 2014, 7, 1-13. [CrossRef]

85. Gutiérrez, A.; Rencoret, J.; Cadena, E.M.; Rico, A.; Barth, D.; del Río, J.C.; Martínez, Á.T. Demonstration of laccase-based removal of lignin from wood and non-wood plant feedstocks. Bioresour. Technol. 2012, 119, 114-122. [CrossRef]

86. Rico, A.; Rencoret, J.; Del Río, J.C.; Martínez, A.T.; Gutiérrez, A. Pretreatment with laccase and a phenolic mediator degrades lignin and enhances saccharification of Eucalyptus feedstock. Biotechnol. Biofuels 2014, 7, 6. [CrossRef] [PubMed]

87. Giacobbe, S.; Pezzella, C.; Lettera, V.; Sannia, G.; Piscitelli, A. Laccase pretreatment for agrofood wastes valorization. Bioresour. Technol. 2018, 265, 59-65. [CrossRef]

88. Giacobbe, S.; Piscitelli, A.; Raganati, F.; Lettera, V.; Sannia, G.; Marzocchella, A.; Pezzella, C. Butanol production from laccasepretreated brewer's spent grain. Biotechnol. Biofuels 2019, 12, 1-8. [CrossRef] [PubMed] 
89. Shanmugam, S.; Krishnaswamy, S.; Chandrababu, R.; Veerabagu, U.; Pugazhendhi, A.; Mathimani, T. Optimal immobilization of Trichoderma asperellum laccase on polymer coated $\mathrm{Fe}_{3} \mathrm{O}_{4} @ \mathrm{SiO}_{2}$ nanoparticles for enhanced biohydrogen production from delignified lignocellulosic biomass. Fuel 2020, 273, 117777. [CrossRef]

90. Steinmetz, V.; Villain-Gambier, M.; Klem, A.; Ziegler, I.; Dumarcay, S.; Trebouet, D. In-situ extraction of depolymerization products by membrane filtration against lignin condensation. Bioresour. Technol. 2020, 311, 123530. [CrossRef] 